\title{
Purification of a 19-kDa pore-forming cytolysin from the sea anemone Heteractis magnifica
}

Karthikayalu S (1, 2), Rama V (2), Venkatesan R (3)

(1) AxioGen Biotech Private Limited, Pondicherry, India; (2) Department of Industrial Biotechnology, Dr. M.G.R. University, Maduravoyal, Chennai, Tamil Nadu, India; (3) National Institute of Ocean Technology, Chennai, Tamil Nadu, India.

\begin{abstract}
Pore-forming cytolysins of $19 \mathrm{kDa}$ from sea anemones present a remarkable cytolytic property. In the present work, a purified 19-kDa cytolysin was obtained from the sea anemone Heteractis magnifica. The purification steps involved ammonium sulfate precipitation and subsequently desalting by dialysis against $10 \mathrm{mM}$ sodium phosphate buffer ( $\mathrm{pH}$ 7.4), followed by anion exchange chromatography in DEAESepharose ${ }^{\circledast}$ column (GE Healthcare, Sweden) and gel filtration chromatography using Sephadex ${ }^{\circledast}$ G-50 matrix (GE Healthcare, Sweden). The active fractions from the gel filtration chromatography were pooled and rechromatographed in the same column. The final active fraction showed a prominent protein band of molecular mass of $19 \mathrm{kDa}$ when analyzed by SDS-PAGE.
\end{abstract}

Key words: Heteractis magnifica, cytolysin, hemolysin, pore-forming toxin.

Sea anemones (class Anthozoa) produce toxins, which are used for capturing prey or as chemical signals to repel predators. A number of toxins have so far been isolated from various species of sea anemones and are well characterized (1-3). Among them, cytolysins of approximately $19 \mathrm{kDa}$ are the most numerous and extensively studied group of cytolysins from sea anemones (2-7). They are monomeric cysteineless proteins with $\mathrm{pH}$ values of above nine and inhibited by sphingomyelin (8-12). They appear to be extremely efficient pore-forming toxins as compared to other members of this class isolated from other organisms $(3,6)$. These 19$\mathrm{kDa}$ cytolysins can efficiently lyse various cells and permeabilize model lipid membranes by using an $\alpha$-helix (8-10). The mechanism of pore formation involves at least two steps: binding of the water soluble monomer to the membrane, and subsequent oligomerization of three to four monomers on the surface of the membrane, leading to the formation of a functional pore with a diameter of $\sim 2 \mathrm{~nm}(8-10)$.

A highly active $19-\mathrm{kD}$ a pore-forming cytolysin has been isolated from the mucus secretion and body homogenate of the sea anemone Heteractis magnifica (13-16). The sea anemone mouth is surrounded by a ring of tentacles that are armed with stinging cells (nematocysts), which are used both in defense and in capturing prey. This cytolysin from the sea anemone $H$. magnifica shares close homology with reported poreforming cytolysins from other sea anemones such as sticholysin I and II from Stichodactyla helianthus, actinoporin (RTX-A) from Heteractis crispa, actinoporin Or-A from Oulactis orientalis and equinatoxin II, IV and V from Actina equina (16).

Though a number of toxins have been identified from sea anemones so far, the purification of the native proteins still remains a challenge. Hence, this study presents simple chromatographic 
methods to purify the native pore-forming toxin from $H$. magnifica.

The sea anemone Heteractis magnifica [identified by Dr. Daphne Fautin (17)] was collected from Andaman Islands, India, at a depth of $5 \mathrm{~m}$ by scuba diving. Samples were deposited in the National Marine Repository at the National Institute of Oceanography, Goa, India. In the laboratory, the live animal was induced by osmotic thermal stress to eject the epithelial mucus that contains the toxins (6). Cnidarian toxins are stored in the cnidocytes, which are intracellular organelles that fire under pressure or osmotic variations and deeply injects the venom. Approximately $2 \mathrm{~kg}$ of anemone was placed in $1 \mathrm{~L}$ of warm distilled water (40 to $45^{\circ} \mathrm{C}$ ) for 15 minutes with intermittent stirring to minimize tissue damage. After 15 minutes, the anemone was removed and the solution was filtered. The filtrate was stored as $100 \mathrm{~mL}$ aliquots in liquid nitrogen during transportation. The extract was removed from liquid nitrogen after transportation and stored at $-70^{\circ} \mathrm{C}$ until analysis. When required, the aliquots were thawed and concentrated by lyophilization and reconstituted in phosphate buffered saline at pH 7.4.

Concentration of the protein was determined by the method described by Lowry et al. (18) using bovine serum albumin (BSA) as the standard.

Hemolytic activity of the toxin was measured quantitatively in terms of attenuance on human red blood cells at room temperature using Spectramax Microtiter ${ }^{\oplus}$ plate reader (Molecular devices, USA). Freshly collected human blood with heparin was centrifuged to remove the buffy coat, and the erythrocytes (RBC) obtained were washed three times in $0.85 \%$ saline and stored at $4^{\circ} \mathrm{C}$. Toxins at desired concentrations were added in the first well to erythrocyte buffer (140 mM NaCl, $10 \mathrm{mM}$ Tris-HCl, $\mathrm{pH}$ 7.4), and then serially diluted two-fold. RBCs $(100 \mu \mathrm{L}$; $\left.D_{630}=0.5\right)$ in erythrocyte buffer were added to the toxins, and hemolysis was monitored by measuring attenuance at $630 \mathrm{~nm}$ for 20 minutes at room temperature. The final volume was 200 $\mu \mathrm{L}$ per well. The percentage of hemolysis was determined at the end of the assay using the following equation of Malovrh et al. (19):

Hemolysis $(\%)=\left(D_{\max }-D_{o b s}\right) /\left(D_{\max }-D_{\min }\right) \times 100$

In which $D_{o b s}$ was the measured attenuance in the well after 20 minutes and $D_{\max }$ is the maximal attenuance by distilled water and $D_{\min }$ is the minimal attenuance by erythrocyte buffer.

The crude extract was treated with ammonium sulfate (Himedia Laboratories, India) to $100 \%$ saturation as per Rosenberg table (20). The mixtures were stirred for 30 minutes at $4^{\circ} \mathrm{C}$ and later centrifuged at $10,000 \times \mathrm{g}$ for 10 minutes at $4^{\circ} \mathrm{C}$. The precipitate was resuspended in $10 \mathrm{mM}$ sodium phosphate buffer ( $\mathrm{pH}$ 7.2) and desalted by dialysis through dialyzing tube with a cutoff at $5,000 \mathrm{Da}$ (Pierce, USA) against $10 \mathrm{mM}$ sodium phosphate buffer at $\mathrm{pH}$ 7.4.

The dialyzed fractions were purified by anion exchange chromatography on Hi-Trap DEAESepharose $e^{\oplus}$ anion-exchange column $(0.7 \times 2.5 \mathrm{~cm})$ (GE Healthcare, Sweden) at a flow rate of 60 $\mathrm{mL} /$ hour (20). Chromatography was performed in an automatic FPLC system, ÄKTApurifier ${ }^{\circledast}$ (GE Healthcare, Sweden) fitted with UV and conductivity monitor and easy-to-use software enabled with automated tracking of the protein and continuous monitoring in real time. The column-stabilizing buffer was $10 \mathrm{mM}$ sodium phosphate buffer, $\mathrm{pH}$ 7.4. One milliliter $(100 \mathrm{mg} /$ $\mathrm{mL}$ ) of sample in the stabilizing buffer was loaded on to the column. After eluting the unbound proteins, the elution of the bound proteins was performed using a linear gradient of sodium chloride from $0 \mathrm{M}$ to $1 \mathrm{M}$ in stabilizing buffer in 60 minutes. The proteins eluted were measured at $280 \mathrm{~nm}$ continuously using UV monitor. Protein peak was tested for hemolytic activity and the fractions under peak showing activity were pooled together, lyophilized and dialyzed against $10 \mathrm{mM}$ sodium phosphate buffer overnight at $4^{\circ} \mathrm{C}$.

The dialyzed fractions from the ion exchange chromatography were subjected to gel filtration chromatography using the FPLC system, ÄKTApurifier ${ }^{\circledast}$ (GE Healthcare, Sweden) (20). Chromatography was performed on a pre-packed Sephadex ${ }^{\oplus}$ G-50 column $(2.5$ x $40 \mathrm{~cm})$, preequilibrated with $10 \mathrm{mM}$ sodium phosphate buffer, $\mathrm{pH} 7.4$, at a flow rate of $30 \mathrm{~mL} /$ hour. One milliliter $(10 \mathrm{mg} / \mathrm{mL})$ of anion-exchange chromatography purified proteins in the running buffer was loaded on the column. Chromatography was performed at $4^{\circ} \mathrm{C}$. The eluted proteins were measured at 280 $\mathrm{nm}$ continuously using UV monitor. The protein peaks collected were tested for hemolytic activity. The active peak was lyophilized, dialyzed against 
$10 \mathrm{mM}$ sodium phosphate buffer overnight at $4^{\circ} \mathrm{C}$ and rechromatographed in the same column under similar running conditions as mentioned above but at a higher flow rate of $60 \mathrm{~mL} /$ hour. The fractions under active peak were concentrated as aforementioned and analyzed by SDS-PAGE.

Protein samples were analyzed by SDS-PAGE, which was performed using 5\% stacking gel and $12 \%$ resolving gels (21). Samples were denatured by boiling in loading buffer containing SDS and $\beta$-mercaptoethanol prior to loading onto the gel. Ten micrograms of purified fractions was loaded on the gel and electrophoresed. Following electrophoresis at $15 \mathrm{~mA}$ for four hours, gels were stained with Coomassie Brilliant Blue R-250 ${ }^{\circ}$ (Himedia Laboratories, India) and destained in a solution of $10 \%(\mathrm{v} / \mathrm{v})$ methanol and $10 \%(\mathrm{v} / \mathrm{v})$ acetic acid.

This paper presents an optimized protocol for the purification of the $19-\mathrm{kDa}$ cytolysins from the sea anemone $H$. magnifica. The proteins from the venom were isolated by salting out process followed by dialysis. The concentration of proteins in the crude venom was $0.24 \mathrm{mg} / \mathrm{mL}$ and in the ammonium sulfate precipitated fraction was 38.6 $\mathrm{mg} / \mathrm{mL}$. The dialyzed fraction was again tested for hemolytic activity and after re-confirming the activity, it was subjected to purification.

Initially, the toxin was purified by the anionexchange chromatography using an automatic FPLC system. In general, 19-kDa pore-forming toxins are basic proteins with $\mathrm{pH}$ values above 9.0. Hence, the toxin was initially purified by anion-exchange chromatography at $\mathrm{pH}$ slightly alkaline $(\mathrm{pH} 7.4)$ to remove the acidic and neutral proteins from the extract. Three major peaks, labeled $\mathrm{A}, \mathrm{B}$ and $\mathrm{C}$ were obtained in a DEAE-Sepharose ${ }^{\varpi}$ column chromatography (GE Healthcare, Sweden) (Figure 1). The peak A showed hemolytic activity. The fractions under peak A were pooled, lyophilized and dialyzed against $10 \mathrm{mM}$ phosphate buffer.

The dialyzed fraction was further purified by gel filtration chromatography in a Sephadex ${ }^{\infty}$ G-50 column (GE Healthcare, Sweden). The size of the pore-forming toxin was $\sim 19 \mathrm{kDa}$. Hence, in the gel filtration chromatography, Sephadex ${ }^{\circ}$ G-50 was selected as the column matrix which has a fractionation range between 1.5 and $30 \mathrm{kDa}$. Purification by gel filtration chromatography yielded three peaks (A, B and C) (Figure 2). The peak B showed hemolytic activity; however, it was overlapped with $\mathrm{A}$ and $\mathrm{C}$ (Figure 2). Hence the fractions under peak B were rechromatographed in the same column under similar conditions but at a higher flow rate of $60 \mathrm{~mL} /$ hour and three peaks $\mathrm{A}, \mathrm{B}$ and $\mathrm{C}$ were obtained (Figure 3). The flow rate was increased to reduce the broadening of the peaks. The peak $\mathrm{B}$ showed hemolytic activity and was concentrated and analyzed by SDS-PAGE. The SDS-PAGE analysis of the purified fractions displayed a single prominent protein band of $\sim 19 \mathrm{kDa}$ (Figure 4 ).

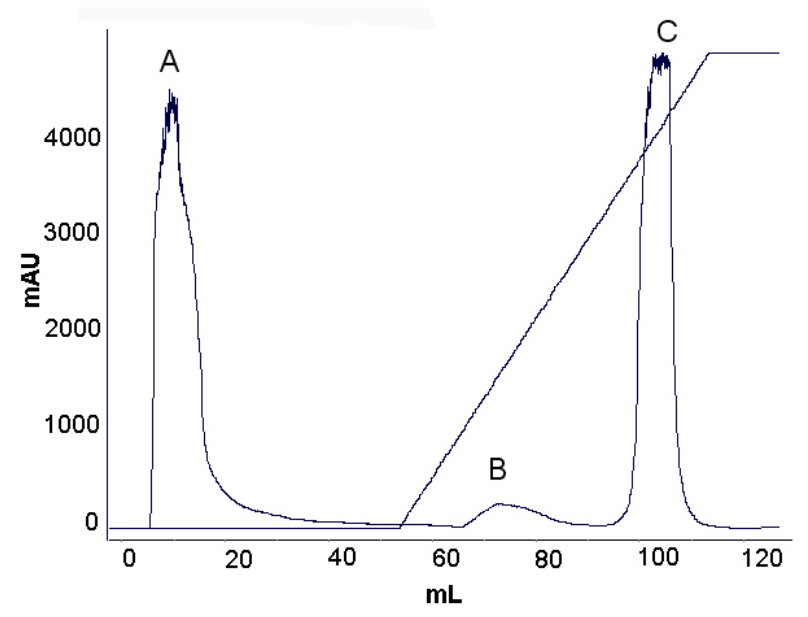

Figure 1. Fractionation of hemolytic crude extract by anion exchange chromatography. $\mathrm{H}$. magnifica crude extract, dissolved in $10 \mathrm{mM}$ sodium phosphate buffer ( $\mathrm{pH}$ 7.4), was fractionated by DEAESepharose ${ }^{\circledast}$ anion-exchange chromatography using a flow rate of $60 \mathrm{~mL} /$ hour. Peak A, corresponding to washout fractions, showed hemolytic activity.

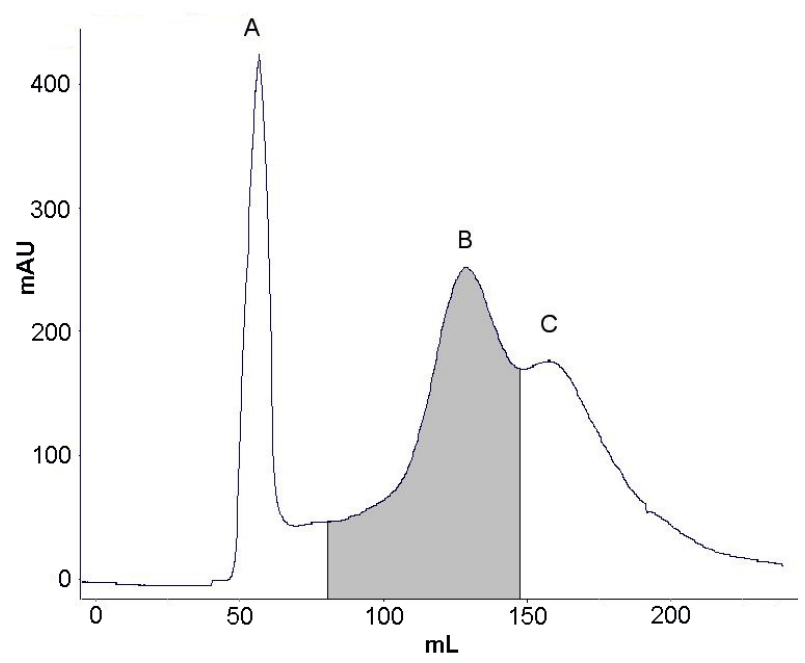

Figure 2. The fractions under peak $A$ in the anionexchange chromatography were pooled and fractionated by gel filtration chromatography at a flow rate of $30 \mathrm{~mL} /$ hour. Peak B exhibited hemolytic activity. 


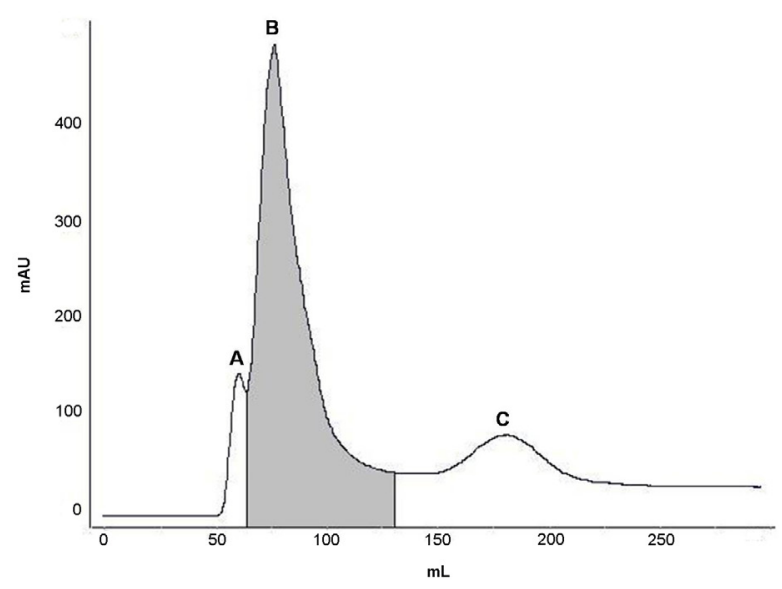

Figure 3. The fractions under peak $B$ in the gel filtration chromatography were pooled and rechromatographed by gel filtration chromatography at a flow rate of $60 \mathrm{~mL} /$ hour. Peak B exhibited hemolytic activity.

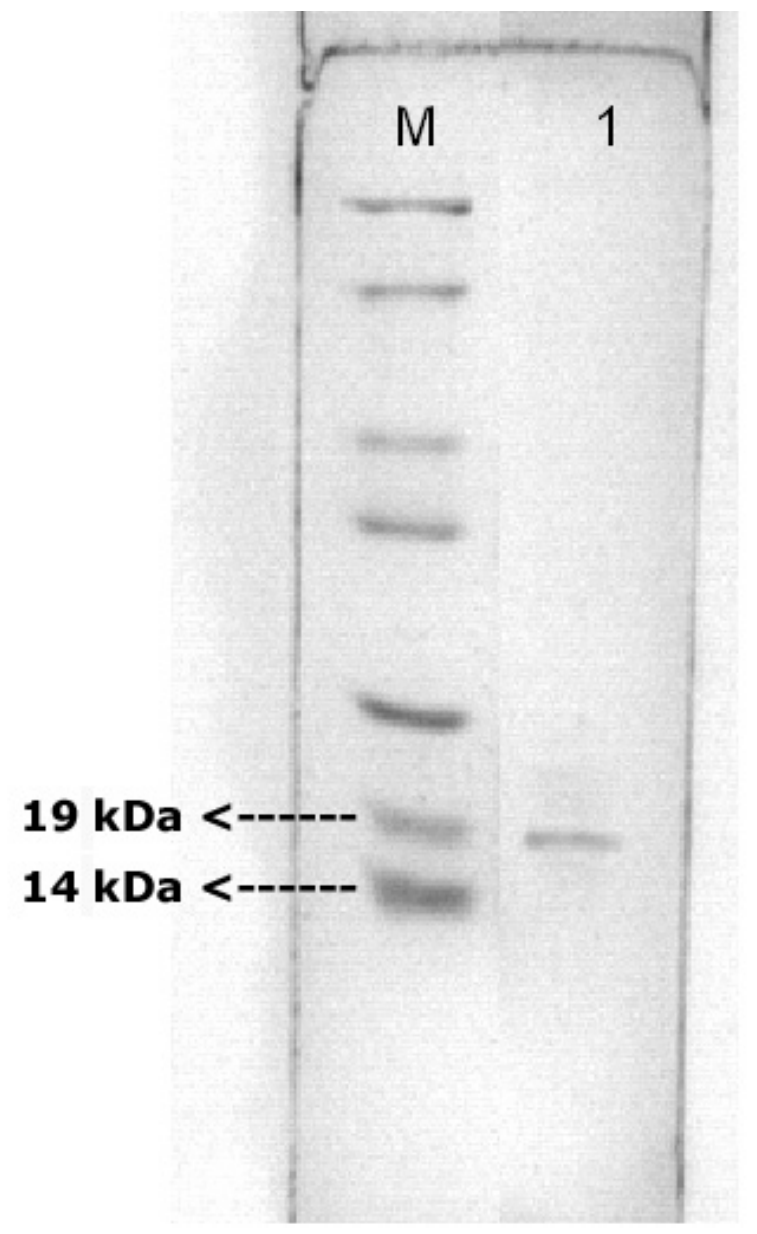

Figure 4. SDS-PAGE analysis of purified fractions. M: standard protein molecular weight marker (Bangalore Genei, India). Lane 1: pooled active fractions from gel filtration chromatography.
Cytolysins of different sizes ranging from short peptides ( 5 to $8 \mathrm{kDa}$ ) to larger proteins $(98 \mathrm{kDa})$ were reported from various species of cnidarians (22). Based on the size and mechanism of action, $19-\mathrm{kDa}$ toxins were termed as poreforming cytolysins and have been identified in almost all species of sea anemones. Being extremely cytolytic and cytotoxic and with the ability to address different tissues, these poreforming cytolysins have been employed in the development of anticancer therapy.

The present study provides a method for the isolation of the native toxin in pure form, thereby facilitating better understanding of the toxin.

\section{COPYRIGHT \\ (C) CEVAP 2010}

\section{SUBMISSION STATUS}

Received: May 12, 2010.

Accepted: May 31, 2010.

Abstract published online: June 21, 2010.

Full paper published online: August 31, 2010.

\section{CONFLICTS OF INTEREST}

There is no conflict.

\section{FINANCIAL SOURCE}

Ministry of Earth Sciences (MoES), Government of India.

\section{CORRESPONDENCE TO}

KARTHIKAYALU SUBBRAYALU, Department of Industrial Biotechnology, Dr. M.G.R. Educational and Research Institute, Dr. M.G.R. University, Maduraoyal, Chennai 600095, India. Phone: +91 4423782176 . Fax: +91 4423783165. Email: karthikayalu@gmail.com.

\section{REFERENCES}

1. Honma T, Shiomi K. Peptide toxins in sea anemones: structural and functional aspects. Mar Biotechnol (NY). 2006;8(1):1-10.

2. Maček $\mathrm{P}$, Lebez $\mathrm{D}$. Isolation and characterization of three lethal and hemolytic toxins from the sea anemone Actina equina L. Toxicon. 1988;26(5):441-51.

3. Anderluh G, Maček P. Cytolytic peptide and protein toxins from sea anemones (Anthozoa: Actiniaria). Toxicon. 2002;40(2):111-24.

4. Anderluh G, Pungerčar J, Štrukelj B, Maček P, Gubenšek F. Cloning, sequencing and expression 
of equinatoxin II. Biochem Biophys Res Commun. 1996;220(2):437-42.

5. Anderluh G, Krizaj I, Štrukelj B, Gubenšek F, Maček P, Pungerčar J. Equinatoxins, poreforming proteins from the sea anemone Actinia equina, belong to a multigene family. Toxicon. 1999;37(10):1391-401.

6. Wang Y, Chua KL, Khoo HE. A new cytolysin from the sea anemone Heteractis magnifica: isolation, cDNA cloning and functional expression. Biochim Biophys Acta. 2000;1478(1):9-18.

7. Maček P. Polypeptide cytolytic toxins from sea anemones (Actiniaria). FEMS Microbiol Immunol. 1992;5(1-3):121-9.

8. Hong Q, Gutierrez-Aguirre I, Barlic A, Malovrh P, Kristan K, Podlesek Z, et al. Two-step membrane binding by equinatoxin II, a pore-forming toxin from the sea anemone, involves an exposed aromatic cluster and a flexible helix. J Biol Chem. 2002;277(1): 41916-24.

9. Anderluh G, Dalla Serra M, Viero G, Guella G, Maček P, Menestrina G. Pore formation by equinatoxin II, a eukaryotic protein toxin, occurs by induction of nonlamellar lipid structures. J Biol Chem. 2003;278(46):45216-23.

10. Kristan K, Podlesek Z, Hojnik V, Gutierrez-Aguirre I, Gunčar G, Turk D, et al. Pore formation by equinatoxin, a eukaryotic pore-forming toxin, requires a flexible $\mathrm{N}$-terminal region and a stable beta sandwich. J Biol Chem. 2004;279(1): 4650917.

11. Athanasiadis A, Anderluh G, Maček P, Turk D. Crystal structure of the soluble form of equinatoxin II, a pore-forming toxin from the sea anemone Actinia equina. Structure. 2001;9(4):341-6.

12. Anderluh G, Barlic A, Podlesek Z, Maček P, Pungerčar J, Gubenšek F, et al. Cysteine-scanning mutagenesis of an eukaryotic pore-forming toxin from sea anemone: topology in lipid membranes. Eur J Biochem. 1999;263(1):128-36.

13. Mebs D, Claus I, Schroter A, Takeya H, Iwanaga S, Gopalakrishnakone P, Tan CK, editors. Recent advances in toxinology research. Singapore: Venom and Toxin Research Group, National University of Singapore; 1992. p. 392-5. 2 vol.

14. Mebs D. Anemonefish symbiosis: vulnerability and resistance of fish to the toxin of the sea anemone. Toxicon. 1994;32(9):1059-68.

15. Khoo KS, Kam WK, Khoo HE, Gopalakrishnakone P, Chung MCM. Purification and partial characterization of two cytolysins from a tropical sea anemone, Heteractis magnifica. Toxicon. 1993;31(12):1567-79.

16. Karthikayalu S, Rama V, Kirubagaran R, Venkatesan $\mathrm{R}$. Characterization, purification and phylogenetic analysis of a cytolysin from the sea anemone Heteractis magnifica of Indian Ocean. J Venom Anim Toxins incl Trop Dis. 2010;16(2):223-40.

17. Fautin DG, Allen GR. Field guide to anemone fishes and their host sea anemones [Internet]. Australia: Western Australian Museum; 1992. Available from: http://jiggeisler.com/reeftank/anemones/ index.htm.

18. Lowry OH, Rosebrough NJ, Farr AL, Randall RJ. Protein measurement with the folin phenol reagent. J Biol Chem. 1951;193(1):265-75.

19. Malovrh P, Macek G, Barlic A, Podlesek Z, Menestrina G, Anderluh G. Structure-function studies of tryptophan mutants of equinatoxin II, a sea anemone pore-forming protein. Biochem J. 2000;346(Pt 1):223-2.

20. Bollag DM, Rozycki MD, Edelstein SJ. Protein Methods. $2^{\text {nd }}$ ed. New York: John Wiley \& Sons Inc.; $1996.415 \mathrm{p}$.

21. Laemmli UK. Cleavage of structural proteins during the assembly of the head of bacteriophage T4. Nature. 1970;227(1):680-5.

22. Karthikayalu S, Rama V, Kirubagaran R, Venkatesan R. Hemolytic toxin from the soft coral Sarcophyton trocheliophorum: isolation and physiological characterization. J Venom Anim Toxins incl Trop Dis. 2010;16(1):107-20 